\title{
Towards Ferry Electrification in the Maritime Sector
}

\author{
Sadia Anwar ${ }^{1, *(\mathbb{D}}$, Muhammad Yousuf Irfan Zia ${ }^{2} \mathbb{D}$, Muhammad Rashid ${ }^{2} \mathbb{D}$, \\ Gerardo Zarazua de Rubens ${ }^{1}$ and Peter Enevoldsen ${ }^{1}$ \\ 1 Department of Business Development and Technology, Aarhus University, 7400 Herning, Denmark; \\ gerardo.zarazua@btech.au.dk (G.Z.d.R.); peterenevoldsen@btech.au.dk (P.E.) \\ 2 Department of Computer Engineering, Umm Al Qura University, 21955 Makkah, Saudi Arabia; \\ myzia@uqu.edu.sa (M.Y.I.Z.); mfelahi@uqu.edu.sa (M.R.) \\ * Correspondence: sadia@btech.au.dk
}

Received: 15 November 2020; Accepted: 7 December 2020; Published: 9 December 2020

\begin{abstract}
The electrification of vessels/ferries for green transformation requires onboard electrical energy storage as well as an energy supply network in the port area. In this context, a lot of efforts have been made in the last decade that have been reviewed in such a way that only a single aspect of the green transformation challenge is highlighted. Consequently, the objective of this research is to develop knowledge by examining the current state of affairs and provide, accordingly, abstract implementation guidelines for green transformation through vessel/ferry electrification. A comprehensive study on the electrification of vessels, in industry as well as in academia, is performed. Based on the data collected through a systematic study, a comparison of various pure electric and hybrid vessels in terms of certain performance attributes, such as battery capacity, passenger and cargo capacities, and size (length) of the vessel, is performed. Moreover, the distribution of vessels according to different countries and manufacturers is provided. Finally, certain technical, operational, and legislative challenges are explored.
\end{abstract}

Keywords: energy storage systems; electrification; electric ferries; green energy; maritime industry

\section{Introduction}

The transportation of commodities (consumer goods) is important, and almost 80 percent of this transportation is carried out using vessels (ships) [1]. At the same time, like any other transportation system, fossil fuels are generally used in the maritime sector, which results in $\mathrm{CO}_{2}$ emissions along with other hazardous gases [2]. Consequently, the maritime industry has an impact on climate change, especially near coastal areas [3]. In this context, the maritime transport sector requires technical developments towards green transformation [4]. Technological improvements for green transformation target the reduction of $\mathrm{CO}_{2}$ emissions along with other hazardous gases, and they ultimately improve the general health of people.

The maritime sector is also important for the international economy. This is particularly true for the European maritime economy, which is associated with short sea operations through ferries, consisting of freight and passenger transport [3]. For example, Europe has approximately 900 ferries (including freight and passenger transport), which accounts for more than $70 \%$ of the world's journeys [5]. The island character of these areas/markets demands intensive transportation through ferries. Fossil fuels are used in most of the ferries and cause emissions such as $\mathrm{CO}_{2}, \mathrm{SO}_{2}$, and $\mathrm{NO}_{\mathbf{X}} \cdot[6,7]$. These emissions have a direct effect on human health when the ferry is berthed [8]. In addition, the emissions of the aforementioned hazardous gases due to ferries being in port areas is higher than other types of ships [9]. It has been stated in [2] that the growth in $\mathrm{SO}_{2}$ and $\mathrm{NO}_{\mathrm{X}}$ emissions has been predicted to exceed the total emission due to shipping fuel consumption by 2030 if no action is taken to address the issue. 
Increasing environmental concerns, as stated in the previous paragraph, have urged the international marine organization (IMO) to implement certain emission regulations [10]. Although ferry operations are of great importance for the European maritime economy, European ferries and vessels do not have the required specifications to counter growing environmental concerns [11,12]. Many ferries that have been operating in the European region for the last twenty years have not been updated, which makes them a critical source of carbon air-polluting emissions [13]. Furthermore, there is an increasing trend towards the electrification of ships through a hybridization process $[14,15]$. In more generic terms, various energy storage systems (ESSs) and renewable energy sources (RESs) are being integrated under the umbrella of the hybridization process [16].

Despite the great importance of ferry electrification, there are certain challenges preventing the successful implementation of this technology. These barriers include technical and operational issues as well as legal and human factors. The technical issues are related to the voyage distance in the case of fully electric ferries. Furthermore, battery charging during the short port stays of electric ferries is also a critical challenge that requires a specialized electrical infrastructure. In addition, the use of lightweight materials is important for the reduction of the weight of electric ships. To improve energy efficiency, the reduction in weight of the ferries, which can be done using special materials, e.g., carbon fiber as an alternative to the steel, is required. In the context of legal challenges, energy regulations, e.g., taxes and ferry construction, are not supportive enough to shift the paradigm towards green energy. In many EU countries, green energy is taxed while hydro-carbon fuels are exempt from taxes. Finally, ferry crews require training in order for them to be familiarized with the technical, operational, and safety issues of the new system [17].

\subsection{State-of-the-Art}

A lot of work has been done to achieve green transformation through ferry electrification. The state-of-the-art to address the aforementioned technical, operational, legal, and human challenges has been reviewed in different works, as summarized in Table 1 [18-27]. The table shows that the existing surveys can be classified into five different categories; namely: (1) electric propulsion, (2) micro-grids, (3) energy storage, (4) fuel cell-battery hybrid/full battery powered ships, and (5) zero-emission ships. In each category, we have provided two recently published surveys to summarize the current state of affairs in each category.

Table 1. Classification of review surveys on various aspects of green transformation.

\begin{tabular}{cccc}
\hline S. No. & Category & Reference & Years \\
\hline 1 & Electric propulsion & {$[18,20]$} & 2020 \\
2 & Micro-grids & {$[19,24]$} & 2019 \\
3 & Energy storage & {$[21,23]$} & 2018,2020 \\
4 & Fuel cell-battery hybrid/full battery powered ships & {$[22,25]$} & 2020 \\
5 & Zero-emission ships & {$[26,27]$} & 2019,2020 \\
\hline
\end{tabular}

In the first category (electric propulsion), an overview of electrical energy sources, propulsion, and power systems is presented in [18]. In order to improve the overall efficiency of ships, the authors in [18] particularly target the conservation and emission of heat energy generated by the engine to the propeller. It has been observed in [18] that the use of electrical power systems decreases energy conversion losses, while direct current (DC) systems provide low fuel consumption as well as decreased emissions. Similarly, several energy efficiency techniques for electric propulsion in ships have been discussed in [20]. The use of liquid gas instead of fossil fuels is beneficial for decreasing the ship's carbon footprint. The authors in [20] have provided several recommendations, e.g., installation of energy storage systems in ships to save fuel. In addition, DC technology needs improvement for it to be used for transmission, and to increasing the availability of DC equipment. These techniques can be combined with new technologies for energy efficiency. Although articles $[18,20]$ provide a thorough 
study on electric propulsion systems, they do not address various energy storage systems. Similarly, different configurations of hybrid and pure electric ships have not been considered.

In the second category, micro-grids and their complete power system design have been discussed. For example, [19] discusses power generation (usually synchronous generator powered by diesel engine), distribution (switchboard and transformer) with high safety and protection, and loads (propulsion and service). It has been concluded in [19] that the ship's energy efficiency depends on the ship design, fuel type, and operations. Furthermore, a case study is presented in [19] to explain the power quality issues in the maritime sector along with a detailed discussion. Similarly, to mitigate the rising environmental issues, carbon emissions, the availability of fossil fuels, and the electrification of the maritime industry including ships, ports, and grids is a hot research area that is discussed in [24]. In the development towards electrification, there is a close relationship between the ships and ports that is related to the engineering and the technology and also to on-grid load management. Micro-grid is a mature technology in the terrestrial environment; however, in the maritime sector there is still great potential to use the technology. The characteristics of electric grids that can be used for port operations, fully electric ships, and the challenges involved in this technology are the main focus of the research in [24]. While the research in $[19,24]$ summarize the typical operating configuration of a complete electrified port, along with its operation scenario, the critical components of a complete green transformation systems such as ESS and propulsion systems have not been discussed.

The third category in Table 1 is related to energy storage systems to improve the fuel efficiency of ships. For example, the work in [23] describes the various types of energy storage systems (batteries) used in the maritime sector. It has been discussed in [23] that all electric ships, to improve the fuel consumption without the emission of hazardous gases, should use the same electrical network to drive the propulsion as well as the service equipment. Similarly, the implementation of sustainability for low carbon emission systems on a priority basis is the focus of work in [21]. There are several renewable energy sources, such as wind energy and photovoltaic, but their integration into the electric grid has some technical challenges. The article presents a solution to improve energy management in such a way that reverse osmosis plants can store the energy in the form of water in islands [21]. The collaboration with marine transportation has also been considered and the use of hydrogen in fuel cells in electric ferries, along with energy storage system (batteries), has been suggested. Because energy storage is the main topic of [21,23], other characteristics of an end-to-end green transformation system have not been discussed.

The fourth category of Table 1 is related to fuel cell-battery hybrid/full battery powered ships. For example, the technical features and environmental impact of fuel cell-batteries are analyzed in [22]. The authors in [22] address the possibilities of using hybrid power systems in the maritime sector because fossil fuel demands that deteriorate the air quality and environment are increasing rapidly. Various technical aspects and the energy strategies of hybrid systems of proton exchange membrane fuel cells and battery systems are compared. It has been discussed in [22] that fuel cells have been successfully implemented in the maritime sector; however, their high price and short life are still a challenge regarding their commercialization. Similarly, the work in [25] explores the advantages of battery systems in electric ferries in place of diesel engines. The research is conducted at various levels. The comparison between the diesel engine and battery operated ships is performed to obtain the carbon footprint using the lifecycle evaluation in three levels, including manufacturing, transport, and operation. The work in [25] provides some corrective directions regarding life cycle assessment.

Finally, in the fifth category (zero-emission ships), the major transitional phases and developments towards green energy in the maritime sector are highlighted. For example, the work in [26] discusses several alternate renewable technologies such as photovoltaic and wind energy. The work in [26] states that large vessel designs could be hybrid and bio-fueled and could be used to reduce emissions. Similarly, the work in [27] discusses the challenges of zero emissions in maritime sector transportation. Future ships could be designed in such a way that they produce slight or zero emissions during operation. The research articles, reviewed in [27], revolve around renewable energy resources that can 
be used to operate ferries with zero emissions. Furthermore, it shows that renewable energy sources can be used to produce both electricity and hydrogen. Subsequently, the electricity and hydrogen are utilized to achieve the zero emission objective. Moreover, it has been observed in [27] that the onshore investment is less for pure electric ferries operating at short distances, while it increases by up to four times for ferries powered by hydrogen fuel.

\subsection{Limitations in the Existing Surveys}

It has been discussed in Section 1.1 that there are various review articles that have been recently published on different aspects of an end-to-end green transformation system. These aspects include onboard electric propulsion systems, micro-grids, energy storage systems, fuel cell-battery hybrid/full battery powered ships, and zero-emission ships. Even though the review articles on these aspects [18-27] have provided great insights in terms of knowledge development for a dedicated or particular aspect of the system, the implementation of these systems (electrification for green transformation) may generally require an abstract implementation guide that can briefly provide an overview (end-to-end knowledge) of the complete system. By end-to-end knowledge development, we mean that the review should not focus on a single problem. Instead, various parameters related to different problems must be addressed in a single article.

\subsection{Contributions}

In order to address the identified limitations, this article has reviewed the state-of-the-art in ferry electrification by examining various aspects of different available commercial vessels (through the internet). Furthermore, data has also been extracted from the associated published literature (case studies) of the products to provide a more comprehensive picture. After systematic data collection, a comprehensive analysis has been performed to extract the useful information. The extracted information allows us to depict various trends such as the countrywide electrification of vessels, leading companies, hybridization versus pure electric ships, size (length) and speed of vessels, passenger and car carrying capacities, battery type and capacity, and so on. The knowledge developed in this article provides a holistic view of the current state of affairs to researchers and practitioners of the domain.

\subsection{Organization}

The article is organized as follows. Section 2 describes the background information on an eco-friendly hybrid propulsion system. Section 3 presents the research methodology. Section 4 presents the results. Section 5 provides a discussion on the electrification of ferries and identifies the challenges, and Section 6 concludes the article.

\section{An Eco-Friendly Hybrid Propulsion System}

The purpose of this section is to provide fundamental concepts related to the electrification of ferries for green transformation. An eco-friendly hybrid propulsion system architecture to reduce emissions and noise pollution near coastal areas is shown in Figure 1. The figure illustrates the charging system at the port that is used to charge the batteries of the vessel from the grid during docking. Several renewable energy sources are also shown in Figure 1, which include: (1) wind energy, (2) photo-voltaic (PV) energy, (3) and energy from surface waves. The energy can be stored in an ESS (consisting of battery banks) when the supply is greater than the demand. 


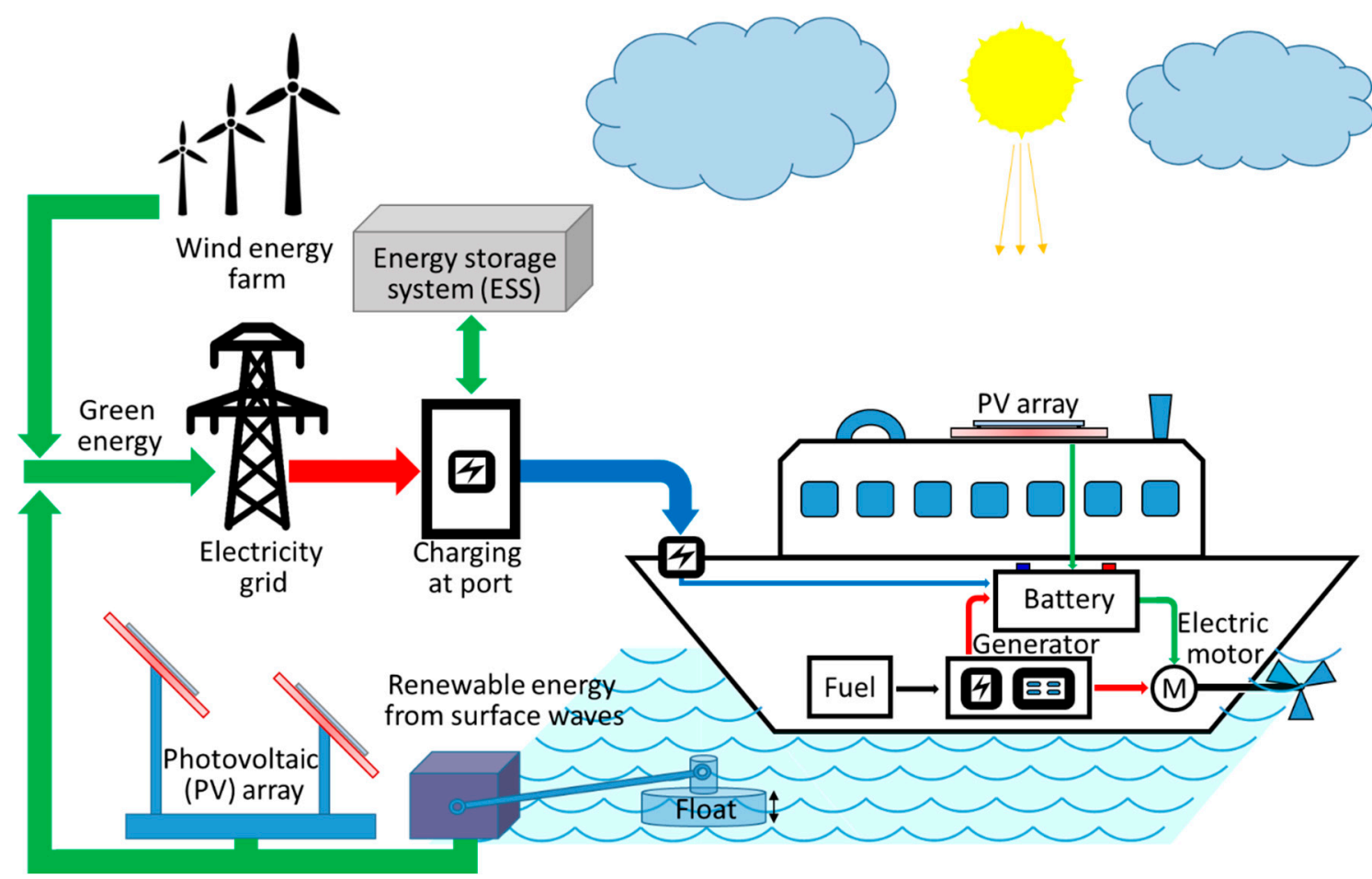

Figure 1. An eco-friendly hybrid propulsion system.

As a typical scenario, a hybrid vessel that has a dual energy system, i.e., (1) an electric generator and (2) the battery bank, to operate the electric motor for propulsion is shown in Figure 1. Because the limited battery capacity is still a challenging problem for green transformation, the hybrid system is useful for extending the possible time of the voyage. The battery capacity, generator size, and fuel type depend upon the type, size, and purpose of the vessel [28]. A PV array is also mounted on the deck of the vessel to charge the battery during daytime [29]. Here it is important to mention that emissions are produced, not only due to the fuel burning in the vessel, but also on the shore, where various types of conventional fuels are used to generate electricity. Consequently, an eco-friendly system is required to address this issue; however, investment is vital for setting up these resources.

The first renewable energy resource in Figure 1 is a wind farm that provides clean energy by converting the wind into electrical energy with the help of turbines [30]. The major benefit of wind energy is that it does not produce carbon dioxide, which is harmful for human health [9]. The wind flows most of the time with varying pressures at coastal areas; however, sufficient land is required to build the wind farms. The PV system, on the other hand, converts solar energy into electrical energy. It also improves the environmental conditions as there is no fuel burning or noise. However, legislation is required to provide some incentives for investors in the sector of solar energy by providing tax exemption or rebates [3]. Moreover, renewable energy can also be produced using surface waves. As wind passes, waves are generated at the surface of the sea and are used to operate a float [31], as shown in Figure 1. The float is connected to a mechanism that converts the oscillatory motion into electrical energy. The electricity, generated by these eco-friendly renewable energy systems, is fed into the main electric grid and used to charge the vessels during docking. Because the renewable energy is generated irrespective of the consumption, an ESS is also installed at the port to store the energy when there is limited or no consumption. The energy is transferred from the ESS to the vessel for charging.

In order to illustrate the aforementioned concepts for pure and hybrid electric ferries, a typical example of a $24 \mathrm{~m}$ long ferry with a capacity of 48 passengers is provided, using the data from case study [32]. For simplification, a fixed speed of 10 knots is used in each case (hybrid/pure electric). The parameters (such as battery capacity, cost, weight, charging requirements) may vary and will 
depend upon a particular scenario/application. In either case (pure electric or hybrid), the battery discharge is considered to be up to $80 \%$ to ensure the battery life. In the first example, a full electric vessel that is equipped with a $500 \mathrm{kWh}$ Lithium-ion (Li-ion) battery is considered. The vessel can travel up to 44 nautical miles $(\mathrm{nm})$ on a single charge [32]. Hence, the pure electric vessel provides a good solution for green transformation but, due to the technology limitations, the cost of a battery pack would be USD $67,500[33,34]$. Additionally, the setup cost of a specialized high power charging station would be quite high, around USD 1 Million [32]. Similarly, the weight of the battery pack would be $3000 \mathrm{~kg}$ [35]. In the second example, a hybrid vessel is considered with a medium sized $300 \mathrm{kWh}$ Li-ion battery that can be used to travel up to 27 nautical miles (nm) on a single charge [32]. Furthermore, to cover a larger distance, the support of gen-set is required. The advantage of this approach is the reduction of battery cost (USD 40,500) [33,34], and the charging station requirements would also be reduced accordingly. The estimated weight would be reduced by up to $1800 \mathrm{~kg}$ [35]. Therefore, a small energy storage system of $160 \mathrm{kWh}$ is used, along with the gen-set that can provide propulsion power up to $14 \mathrm{~nm}$. The cost of the battery pack would be reduced to USD 21,600 [33,34] and the weight would be $960 \mathrm{~kg}$ [35]. The aforementioned examples illustrate that there is always a tradeoff in the selection of an optimized solution for green transformation.

\section{Research Methods}

This part outlines the research methodology considered in this article and applies mixed method approaches, combining both qualitative and quantitative studies. The selection of mixed methods is necessary because the maritime sector operates on quantities and materials. Figure 2 shows that the research framework model in this article consists of three steps: (1) design research, (2) conduct research, (3) data analysis and conclusion.

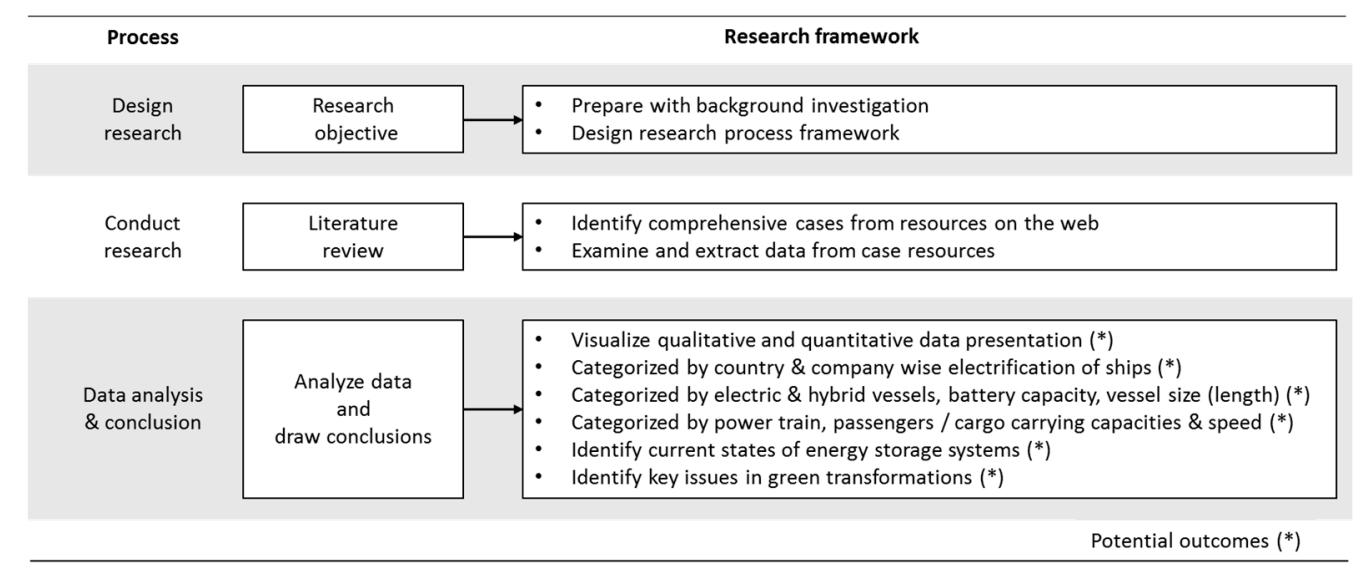

Figure 2. Research framework model.

\subsection{Design Research}

The first step in the methodology is the research design. In this step, the purpose of the research (background investigation) has to be highlighted. In order to identify the core objective for the research, a comprehensive study of existing review papers is needed. The introductory part of this article has already provided the relevant details on existing survey papers [18-27], revolving around five distinct categories: (1) electric propulsion, (2) micro-grids, (3) energy storage systems, (4) fuel cell-battery hybrid/full battery powered ships, and (5) zero-emission ships. Although the existing review articles on ferry electrification for green transformation [18-27] are a great source for knowledge development, they are specialized only for a particular aspect of the system. Therefore, the research objective, and hence the research design, in this article is to provide implantation guidelines that can briefly 
provide an overview (end-to-end knowledge) of the complete vessel electrification system without going into the complete implementation details.

\subsection{Conduct Research}

Figure 2 shows that the research is conducted through a comprehensive literature review to identify potential cases from resources on the internet and in publications. The literature review conduction in this article is similar to [30] in the sense of its research strategy, while it differs from the case studies in the manner of its searching method and analysis procedure. The summary of the literature review process, consisting of three steps, is shown in Figure 3. These three steps are: (1) search keywords, (2) case selection, and (3) data collection.

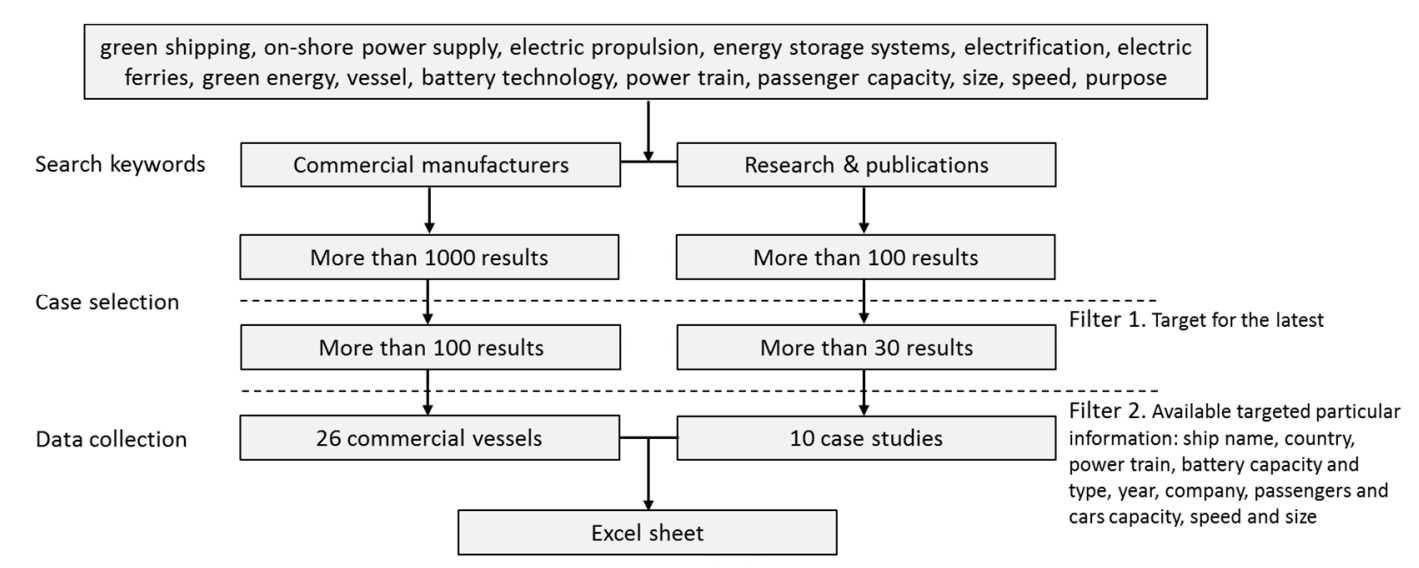

Figure 3. Details of conduct research step in the research framework model.

\subsubsection{Search Keywords}

With the objective of providing knowledge for green transformation, a literature review through existing regulations, articles, and conference papers has been carried out by searching for keywords in online databases such as Scopus, Web of Science, and Google Scholar. The keywords generated for the research were "green shipping", "on-shore power supply", "electric propulsion", "energy storage systems", "electrification", "electric ferries", "green energy", "vessels", "battery technology", "power train", "passengers capacity", "size", "speed", and "purpose" in an "and" combination with "maritime". The searching brought about a large number of results; therefore, second-level keywords, including "Europe", "barrier", and "policy" are used to search the most relevant literature because, in Europe, the maritime industry is one of the more mature and supportive industries where North Europe aims to take a leading role. The keywords were searched for both on the Internet and from research and publications (case studies). Due to data accessibility, this study investigated open resources from online documents (data from manufacturers). At the same time, the current case studies (research and publications) have taken an exploratory approach inspired by [36] to demonstrate the status of technologies embedded in different vessels with a view towards electrification.

\subsubsection{Case Selection}

In addition to the selection of keywords, a selection/rejection criterion is equally important and is purely dependent on the context of the research. The examples of various selection/rejection criteria in different engineering domains are provided in [37-39]. Consequently, in order to have the latest information, the authors searched for vessels launched from 2008 to 2019. Meanwhile, aiming for a holistic vision of the vessel, the authors searched for one that had all of the following parameters: ship name, country, company, year, power train, types of battery used, battery capacity, passengers and cargo information, speed, and size, and they skipped the ones without these required data. The search revealed a variety of information including more than a thousand vessels, and only a few of them had 
all the aforementioned information. Therefore, the authors went through all these websites and filtered cases one by one. A total of 26 commercialized vessels were deemed relevant for study, together with 10 cases from available research publications that proposed possible changes in already commercialized vessels by hypothesizing and using MATLAB/Simulink software for research and development (R\&D) purposes. This was done with the hope of acquiring a comprehensive and generative knowledge from representative cases in the maritime sector.

After examining and focusing on the selected intrinsic parameters, the remaining most recent 30 articles were the main focus of this study, and they will be elaborated on according to their different focuses in the maritime sector. Figure 3 provides the reader with an overview of these findings. The achievement of this procedure will be the basis for targeting the parameters, thus establishing knowledge from various essential perspectives when considering green transformation. The logic for the selection of the 26 vessels was that if the selected one represented the same technology present in many available vessels, there would be no need to survey all of them. The other reason for the selection of the 26 vessels and the 10 cases was because they contained the required parameters and because not all parameters could be found through surveys conducted through online internet and research publication findings.

\subsubsection{Data Collection}

Finally, the data was gathered through a review of papers, reports, websites, and online surveys, and a mixed method research approach was utilized. Documents were collated, and the relevant data extracted in an MS Excel spreadsheet in different columns. Subsequently, the target parameters were presented using tables. It is important to note that we selected the most appropriate keywords and comprehensively filtered the obtained results. Nevertheless, the selected keywords resulted in thousands of documents and therefore it was difficult to perform an exhaustive scan of the obtained documents. Moreover, several obtained documents were rejected, because it was quite possible that the title of the rejected research may not have represented the contents in an appropriate way. Therefore, no claim is made on the completeness of the research in this article.

Once the data was collected (through the steps of Figure 3), it was followed by a data analysis and conclusion step, as shown in Figure 2.

\subsection{Data Analysis and Conclusions}

In the analysis section, techniques based on graphical analysis were applied. The collected material was clustered, and the data was further organized and formatted corresponding to a coding framework. The framework contained two main categories. One was countrywide electrification of ships and leading stakeholders, the other was the mechanical factors of a vessel, which were battery capacity, size (length), and passenger and cargo capacities of pure electric and hybrid vessels. Data gathered from the material were examined and analyzed. The categories of the framework were deductively developed according to the previous reviews of crucial perspectives from the maritime area. The parameters, e.g., ship name, country and company, power train, types of battery used, and intended use are generally non-numeric fields and fall into the category of qualitative data. The other quantifiable fields, such as battery capacity, passengers and cargo information, speed, and size (length) of the vessels are measurable items. The data was statistically analyzed to find the trends. This study is also helpful in reducing the noise pollution and environmental impact during docking of the vessels to optimize the utilization of battery operation and reduce the emissions of $\mathrm{CO}_{2}$ and other toxic materials.

\section{Results}

This section first provides the data extraction using Table 2 (for electric and hybrid vessels) and Table 3 (for case studies) in Section 4.1. Subsequently, the data synthesis is presented using different 
graphs in Section 4.2. Finally, the discussion on various parameters of frequently used energy storage systems (batteries) is provided in Section 4.3.

\subsection{Data Extraction}

The vessels designed or modified for electrification to achieve green transformation are presented in Table $2[33,34,40-63]$. The name of the ship in Column 2 of Table 2 is followed by the country name in Column 3. The power trains (Column 4) are either electric (purely battery operated) or hybrid (batteries along with a diesel engine or fuel cell). The battery capacity (in kWh) and type are provided in Column 5 and Column 6, respectively. Similarly, the year of manufacturing and the name of the company are provided in Column 7 and Column 8, respectively. Finally, the parameters, such as passengers, car carrying capacity, cruising speed, and size (length) of the vessels are provided in Columns 9-12, respectively.

The data in Table 2 is organized in chronological order (year of manufacture). In this context, Zemships from Germany [40] designed a hybrid vessel, named the FSC Alsterwasser, in 2008 with a battery capacity of $200 \mathrm{kWh}$. The passenger capacity is 100 and it can sail with a speed of 8 knots. The most recent entries (2019) in Table 2 are Ellen from Denmark [43], MV Waterman from the USA [60], and MS Color Hybrid from Norway [63]. The passenger capacities in these vessels are 200, 150, and 2000, respectively. Similarly, the battery capacity in these vessels are 4300, 80, and $5000 \mathrm{kWh}$, respectively. The differences in battery capacities is due to the power train and size of the ships. For example, the battery capacity in Ellen [43] is 4300 because its power train is pure electric, while the power train of MV Waterman [60] is hybrid and, therefore, the battery requirement is $80 \mathrm{kWh}$. Furthermore, the higher battery capacity requirement (5000 kWh) of the MS Color Hybrid ferry [63] is due to its passenger carrying capacity (2000 persons).

While Table 2 provides the data, extracted directly from the websites of manufacturers, Table 3 summarizes some important $R \& D$ projects [32,64-72] related to ferry electrification. The information in Table 3 is organized in a fashion similar to Table 2, except that the year of manufacture in Column 7 of Table 2 is replaced with the year of publication in Column 7 of Table 3. 
Table 2. Vessel study for battery technology towards electrification.

\begin{tabular}{|c|c|c|c|c|c|c|c|c|c|c|c|}
\hline Ref. No. & Name & Country & $\begin{array}{l}\text { Power } \\
\text { Train }\end{array}$ & $\begin{array}{l}\text { Battery } \\
\text { (kWh) }\end{array}$ & Battery Type & Year & Company & Passengers & Cars & $\begin{array}{c}\text { Speed } \\
\text { (knots) }\end{array}$ & Length (m) \\
\hline [40] & FSC Alsterwasser & Germany & Hybrid & 200 & Lead-Gel & 2008 & Zemships & 100 & - & 8 & 25 \\
\hline [41] & Nemo H2 & Nether-lands & Hybrid & 70 & - & 2009 & Govt. and Industry & 87 & - & 9 & 22 \\
\hline$[42]$ & Viking Lady & Norway & Hybrid & 500 & Li-ion & 2009 & Eidesvik & 25 & - & 15.5 & 92 \\
\hline [46] & MV Hallaig & Scotland & Hybrid & 700 & Li-ion & 2012 & CalMac Ferries Ltd & 150 & 23 & 9 & 43 \\
\hline [47] & MV Lochinvar & Scotland & Hybrid & 700 & Li-ion & 2013 & CalMac Ferries Ltd & 150 & 23 & 9 & 43 \\
\hline [49] & $\begin{array}{l}\text { Prinsesse } \\
\text { Benedikte }\end{array}$ & Denmark & Hybrid & 1600 & Li-ion & 2013 & Scandlines & 1140 & 364 & 18.5 & 142 \\
\hline [50] & Prins Richard & Denmark & Hybrid & 1600 & Li-ion & 2014 & Scandlines & 1140 & 364 & 18.5 & 142 \\
\hline [51] & $\mathrm{M} / \mathrm{F}$ Deutschland & Germany & Hybrid & 1600 & Li-polymer & 2014 & Scandlines & 1200 & 364 & 18.5 & 142 \\
\hline [52] & M/S Sjovagen & Sweden & Electric & 500 & Li-ion & 2014 & Ballerina & 150 & - & 8.5 & 24.5 \\
\hline [53] & Movitz & Sweden & Electric & 120 & $\mathrm{NiMH}$ & 2014 & Echandia Marine & 100 & - & 9 & 22.8 \\
\hline [54] & MV Ampere & Norway & Electric & 1000 & Li-ion & 2015 & Norled & 360 & - & 10 & 79 \\
\hline [55] & MV Island Clipper & Norway & Hybrid & 875 & Li-ion & 2015 & $\begin{array}{l}\text { Inland Offshore } \\
\text { Management AS }\end{array}$ & 56 & - & 15 & 97 \\
\hline [61] & BB Green & Nether-lands & Hybrid & 200 & Li-ion & 2015 & $\begin{array}{l}\text { Partly funded by an } \\
\text { EU dev. project }\end{array}$ & 100 & - & 30 & 22 \\
\hline [45] & $\begin{array}{l}\text { Vision of the } \\
\text { Fjords }\end{array}$ & Norway & Hybrid & 600 & Li-ion & 2016 & The Fjords & 399 & - & 19.5 & 40 \\
\hline [48] & MV Catriona & Scotland & Hybrid & 700 & Li-ion & 2016 & CalMac Ferries Ltd & 150 & 23 & 9 & 43 \\
\hline [56] & OV Bokfjord & Denmark & Hybrid & 850 & Li-ion & 2016 & Hvide Sande Shipyard & 16 & - & 13.5 & 44 \\
\hline$[62]$ & Aditya & India & Electric & 50 & Li-ion & 2016 & $\begin{array}{l}\text { Kerala State Water } \\
\text { Transport Dept. }\end{array}$ & 75 & - & 7.5 & 21 \\
\hline [33] & MF Tycho Brahe & Denmark & Electric & 4100 & Li-ion & 2017 & Scandlines & 1250 & 240 & 14.5 & 111 \\
\hline [34] & Elektra & Finland & Hybrid & 1000 & Li-ion & 2017 & Finferries & 375 & 90 & 11 & 98 \\
\hline [57] & Viking Princess & Norway & Hybrid & 511 & Li-ion & 2017 & Eidesvik & 28 & - & 11.4 & 90 \\
\hline [58] & $\begin{array}{c}\text { Zhongtiandianyun } \\
001\end{array}$ & China & Electric & 2400 & Li-ion & 2017 & $\begin{array}{c}\text { Guangzhou Shipyard } \\
\text { International }\end{array}$ & - & - & 7 & 70 \\
\hline [44] & $\begin{array}{l}\text { Future of the } \\
\text { Fjords }\end{array}$ & Norway & Electric & 1800 & Li-ion & 2018 & The Fjords & 400 & - & 16 & 43 \\
\hline [59] & Enhydra & USA & Hybrid & 160 & Li-ion & 2018 & Red \& White Fleet & 600 & - & 13 & 39 \\
\hline [43] & Ellen & Denmark & Electric & 4300 & Li-ion & 2019 & EU H2020 & 200 & - & 21 & 60 \\
\hline [60] & MV Waterman & USA & Hybrid & 80 & Li-ion & 2019 & $\begin{array}{l}\text { All America Marine, } \\
\text { Inc. }\end{array}$ & 150 & - & 15 & 21 \\
\hline [63] & MS Color Hybrid & Norway & Hybrid & 5000 & Li-ion & 2019 & Color Line & 2000 & - & 17 & 160 \\
\hline
\end{tabular}


Table 3. Case studies through research and publications.

\begin{tabular}{|c|c|c|c|c|c|c|c|c|c|c|c|}
\hline $\begin{array}{l}\dot{0} \\
Z \\
\Psi \\
\simeq\end{array}$ & $\begin{array}{l}\underset{\Xi}{\Xi} \\
\text { Z゙ }\end{array}$ & $\begin{array}{l}\stackrel{R}{E} \\
\Xi \\
0\end{array}$ & 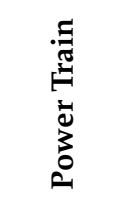 & 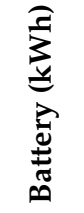 & $\underset{\infty}{\stackrel{D}{D}}$ & シี & $\frac{\overrightarrow{\tilde{U}}}{\stackrel{\circ}{O}}$ & 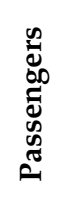 & uี & 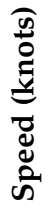 & 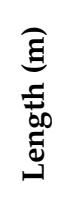 \\
\hline [66] & Glutra Ferry & Norway & Hybrid & - & - & 2002 & R\&D & - & 100 & 12 & 94.8 \\
\hline [64] & Boat & Italy & Electric & 226.8 & Li-ion & 2011 & R\&D & - & - & 6 & - \\
\hline [72] & Alsterwasser & Germany & Hybrid & 200 & Lead-Gel & 2014 & R\&D & 100 & 200 & 8 & 25 \\
\hline [32] & $\begin{array}{l}\text { Typical } \\
\text { Shuttle }\end{array}$ & Italy & Hybrid & $\begin{array}{l}500, \\
300, \\
160\end{array}$ & Li-ion & 2015 & R\&D & 48 & - & 13 & 24 \\
\hline [67] & Hybrid ship & China & Hybrid & - & $\mathrm{LiFePO} 4$ & 2016 & $R \& D$ & - & - & - & 333 \\
\hline [68] & Alsterwasser & Germany & Hybrid & 200 & Lead-Gel & 2016 & R\&D & 100 & - & 8 & 25 \\
\hline [69] & Alsterwasser & Germany & Hybrid & 200 & Lead-Gel & 2016 & R\&D & 100 & - & 8 & 25 \\
\hline [71] & M/S Smyril & Denmark & Hybrid & 300 & Li-ion & 2016 & R\&D & 976 & - & 21 & 123 \\
\hline [65] & Bowen Ferry & Australia & Hybrid & 13.7 & - & 2018 & R\&D & - & 30 & 7 & 35 \\
\hline [70] & $\begin{array}{l}\text { Skeena } \\
\text { Queen }\end{array}$ & Canada & Hybrid & 360 & - & 2019 & R\&D & 600 & - & 14 & 110 \\
\hline
\end{tabular}

\subsection{Data Synthesis}

Based on the data presented in Tables 2 and 3, this section interprets/synthesizes the data to reveal some meaningful information. For example, Figure 4 shows the countrywide electrification of ships (both pure electric and hybrid) in the last decade. In this context, the data can be classified into three categories. The first category consists of three countries: Scotland, Denmark, and Norway. The countries in the first category have electrified three, five, and seven ships, respectively, and play a leading role in this technology. The second category consists of Germany, the Netherlands, Sweden, and the USA, in that each country in this category has electrified two ships. Finally, the third category includes China, Finland, and India, who have each electrified one ship in the last decade. It is important to note that the countrywide electrification of ships in Figure 4 is purely based on the data presented in Table 2. The data in Table 3 is mainly related to some R\&D activities and are, therefore, not included in Figure 4.

In addition to countrywide electrification, companywide electrification of vessels is equally important and is shown in Figure 5, which depicts the companywide electrification for the period 2008-2019. It can be seen that Zemships (Germany) [40] started the process in 2008, followed by the Govt. and Industrial project (Netherlands) [41] and Eidesvik (Norway) [42] in 2009. After a gap of two years, CalMac Ferries Ltd. (Scotland) built two ships [46,47] in 2012 and 2013. Scandlines (Denmark) electrified a ship [49] in 2013 and two ships [50,51] in 2014. Two more companies, Ballerina [52] and Echandia Marine [53] (both from Sweden) built ships in 2014. The two Norwegian companies, Norled [54] and Inland Offshore Management AS [55], as well as a project partially funded by an EU development project [61] in the Netherlands, electrified ships in 2015. Four ships were electrified in 2016 by The Fjords (Norway) [45], CalMac Ferries Ltd. (Scotland) [48], Hvide Sande Shipyard (Denmark) [56], and Kerala State Water Transport Department (India) [62]. In 2017, four vessels were electrified by Scandlines (Denmark) [33], Finferries (Finland) [34], Eidesvik (Norway) [57], and Guangzhou Shipyard International (China) [58]. The Fjords (Norway) [44] and Red and White Fleet (USA) [59] electrified two ships in 2018. Three ships were electrified in 2019 by the EU H2020 Project (Denmark) [43], All American Marine, Inc. (USA) [60], and Color Line (Norway) [63]. 


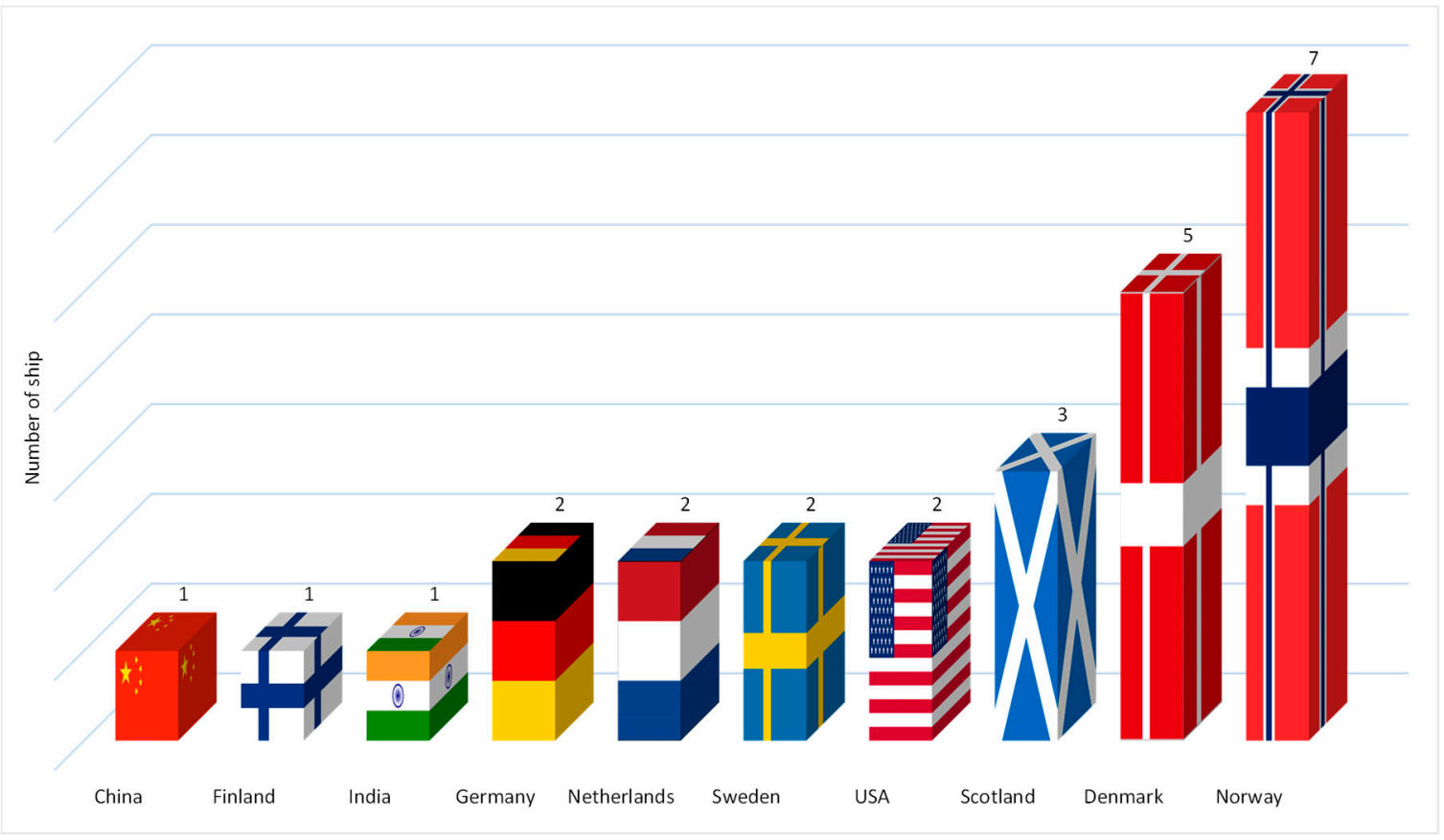

Figure 4. Countrywide electrification of ships.



Figure 5. Companywide electrification of ships.

While Figures 4 and 5 provide a classification of vessels according to different countries and companies, respectively, a classification of vessels according to battery capacity and ship size (length) is provided in Figure 6. It has been shown in Figure 6 that the ships designed in the last decade can be classified into pure electric (31\%) and hybrid (69\%). The figure has a dual scale; the battery capacity range is shown on the left hand side in $\mathrm{kWh}$, while the vessel size is shown on the right hand side in meters. 


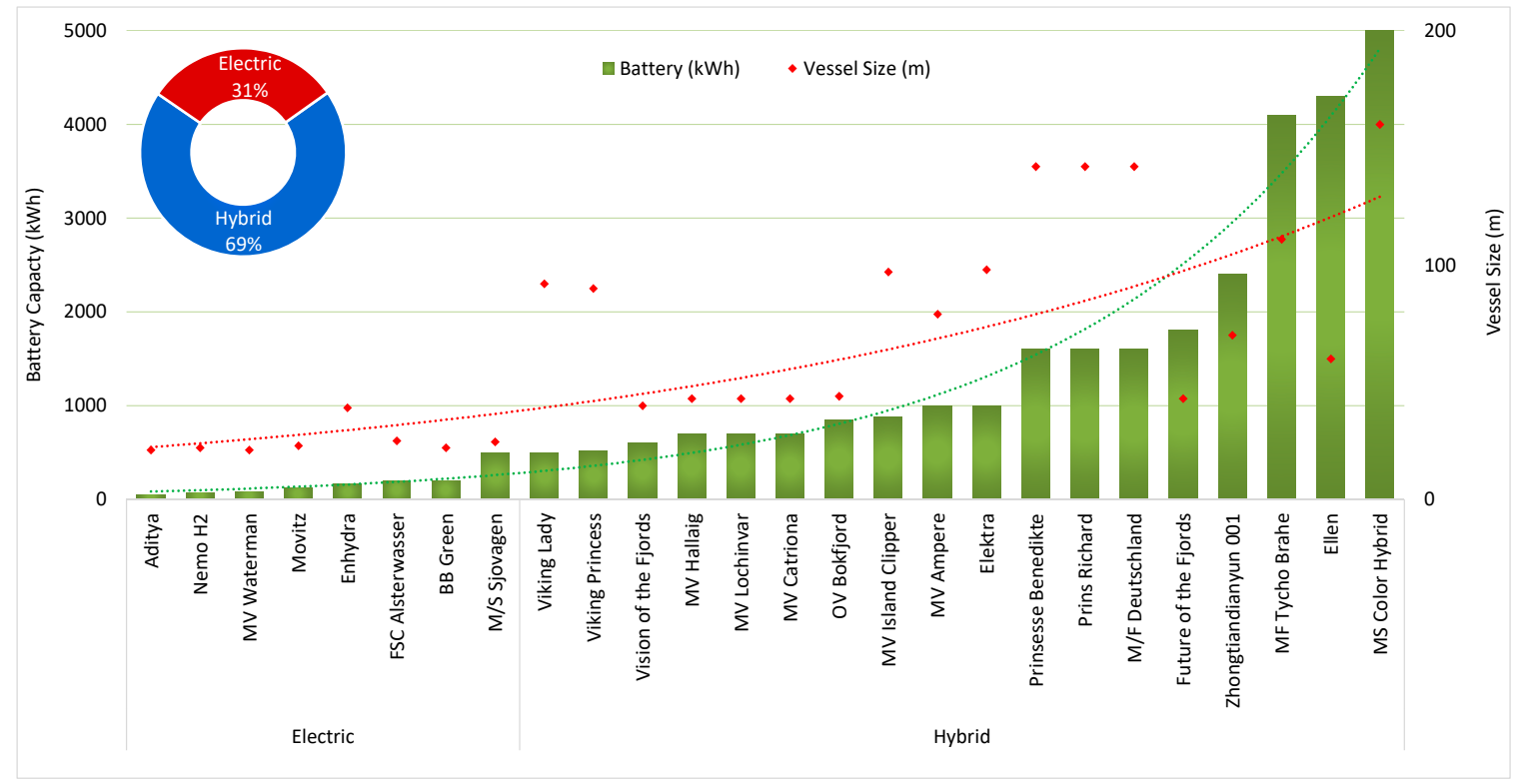

Figure 6. Electric and hybrid vessels (Battery capacity and vessel length).

The battery capacity used in pure electric vessels is in the range of 50-500 $\mathrm{kWh}$, with a median value of $140 \mathrm{kWh}$, while, in hybrid ships, the range is $500-5000 \mathrm{kWh}$, with a median of $1000 \mathrm{kWh}$. From the analysis, it is clear that hybrid technology (used in $69 \%$ of the vessels) has an almost 10 times larger battery capacity compared to the pure electric vessels. The pure electric vessel length is in the range of 21-39 m, with a median at $22 \mathrm{~m}$, while the hybrid ship lengths are in the range of 40-160 m, with a median of $84.5 \mathrm{~m}$. The difference between lengths is at least twice at minimum range, while this difference in size becomes four times at maximum values. Finally, the green dotted line shows the trend of battery capacity in $\mathrm{kWh}$ for different electric and hybrid vessels, and the red dotted line shows the trend of vessel length for various electric and hybrid vessels.

Similar to Figure 6, Figure 7 classifies the pure electric and hybrid technology on the basis of three parameters: (1) passengers capacity, (2) car carrying capacity, and (3) the maximum speed of the vessel. The figure has a dual scale; the passenger and car capacity are shown on the left side of the graph, while the vessel speed in knots is shown on the right side of the graph. It is obvious from Figure 7 that the passenger capacity of pure electric vessels is in the range of 75-1250, with a median value of 200 persons. It is important to note that only some of the vessels (and not all the vessels) can also carry up to 240 cars. On the other hand, the hybrid vessels can transport 16-2000 passengers with a median value of 150 personnel, but in addition they can also carry 23-364 cars depending upon their size. The speed of pure electric vessels is in the range of 7-21 knots, with a median value of 9.5 knots, while hybrid ships use $8-30$ knots with a median value of 14.25 knots. From the analysis, it can be seen that the speed of hybrid vessels is almost 1.5 times greater than that of pure electric vessels. Finally, the blue dotted line shows the trend of passenger capacity for several electric and hybrid vessels, and the red dotted line shows the trend of the maximum speed of various electric and hybrid vessels. The trend for car carrying capacity is not shown in Figure 7 because not all the vessels have this facility.

The aforementioned Figures 4-7 have portrayed some valuable information related to green transformation in the maritime sector. In addition to previously discussed parameters, the information about the application of a particular vessel in the last ten years may provide an overall idea about their usage. Consequently, Figure 8 provides the distribution of vessels according to their use. 


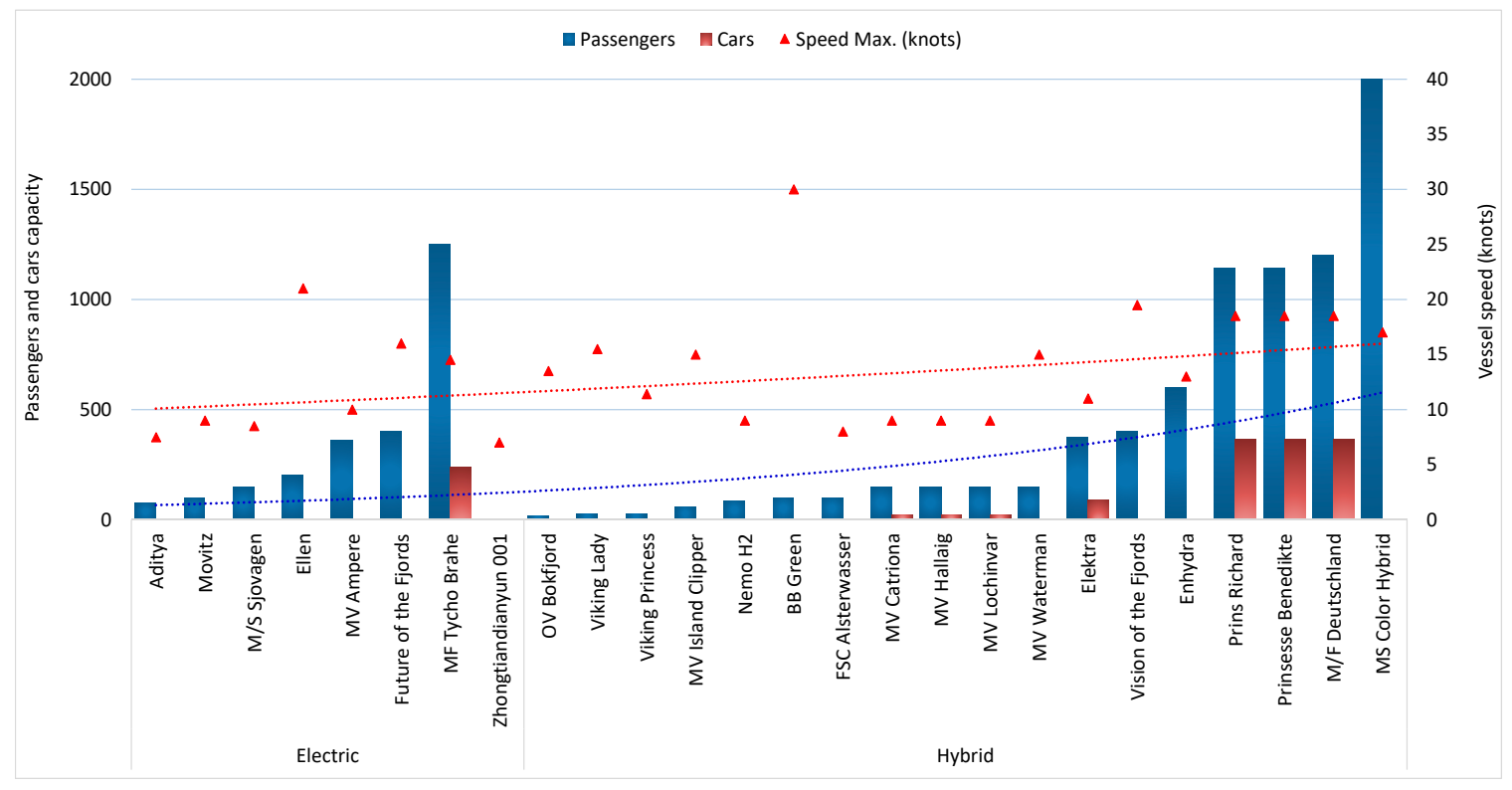

Figure 7. Electric and hybrid vessels (Passenger/car capacity and vessel speed)).

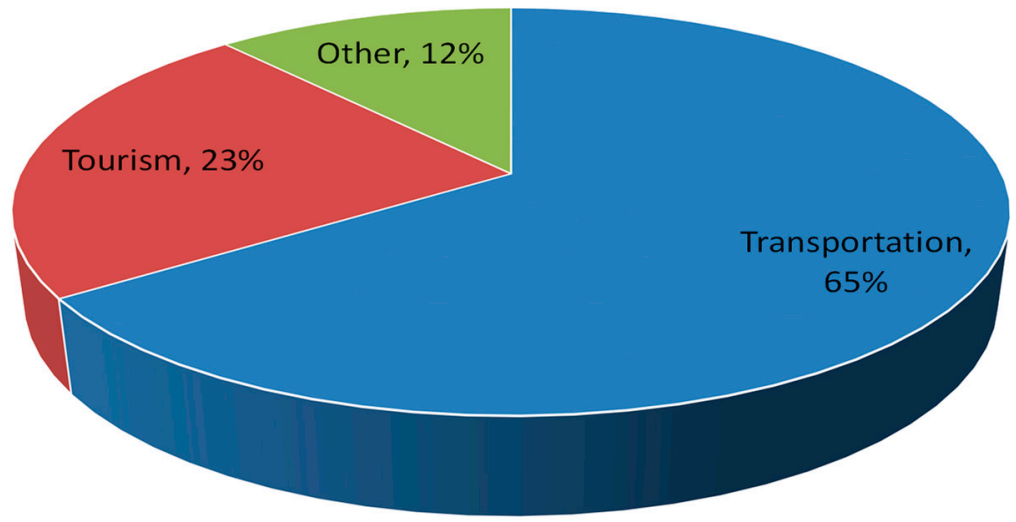

Figure 8. Electric and hybrid vessels.

It can be observed from Figure 8 that the usage of vessels in the context of green transformation can be distributed into three categories: (1) Transportation, (2) Tourism, and (3) Other. The transportation category is related to the movement of passengers from one place to another for their daily routines, e.g., work, and has the widest use (65\% of the total vessels) [63]. In addition to the transportation of passengers, another major use of vessels is in the tourism sector. It has been found that $23 \%$ of the total vessels in the last ten years (according to Tables 2 and 3) have been particularly designed for tourism [43]. Finally, the remaining $12 \%$ of vessels are used for miscellaneous applications such as a multi-purpose use or the offshore supply of oil and gas $[42,55,56]$.

\subsection{Energy Storage System (ESS): Batteries}

Sections 4.1 and 4.2 have summarized various parameters of electric/hybrid vessels for green transformation. However, the most critical parameter in electric/hybrid vessels is the energy storage system. Therefore, this section highlights some important issues related to the most frequently used battery technology. It is important to note that this section is not going to target the leading manufacturers of energy storage systems in electric/hybrid vessels, as this list can be seen in [73]. Similarly, the cost analysis of various products from the leading manufacturers is presented in [74]. In addition to the list of manufacturers and cost analysis, the life cycle analysis of frequently used 
batteries in the context of electric/hybrid vessels has already been discussed in [75]. Readers are requested to please consult references [73-75] for more details on these issues. Consequently, this section discusses various configurations of energy storage systems along with a discussion on frequently used Li-ion batteries.

Traditionally, fossil fuels are used in ferries to operate the main engine for propulsion and to provide electricity for appliances. Various efforts have been made for a green transformation from fossil fuel to battery operation to reduce $\mathrm{CO}_{2}$ emissions and noise level, especially in highly populated areas. From a propulsion point of view, battery operation can be divided into two categories/configurations.

In the first case, fully electric vessels use large battery banks to drive an electric motor; however, in these cases, regular charging of the batteries is a challenge. In addition, the continuous use of batteries requires a suitable cooling system for satisfactory performance and battery life. Due to limited battery capacity and high energy requirements, this system is used in vessels used for short distances and limited time operations. The battery bank of the vessel is charged from the shore grid; however, a small generator is available to charge batteries in emergency situations.

In the second option, i.e., hybrid propulsion systems, a typical diesel or gasoline engine along with the battery bank is used to operate an electric motor. This system allows the vessel to travel longer distances. The batteries are used at lower speed, especially at the time of docking to ensure zero-emissions. The electrification of a vessel depends highly upon the battery system, which includes the dimension, weight, recharging time, lifetime, cost, the cooling system, and recycling.

From the study of state-of-the-art commercial vessels in Table 2 and the case studies in Table 3 , we found that battery technology has moved from lead-acid to Li-ion batteries [28]. One of the major reasons for this is the cost, which has declined from USD 917 to USD 135 in the last decade and is expected to be reduced to USD 100 in 2021, as shown in Figure 9 [33,34].

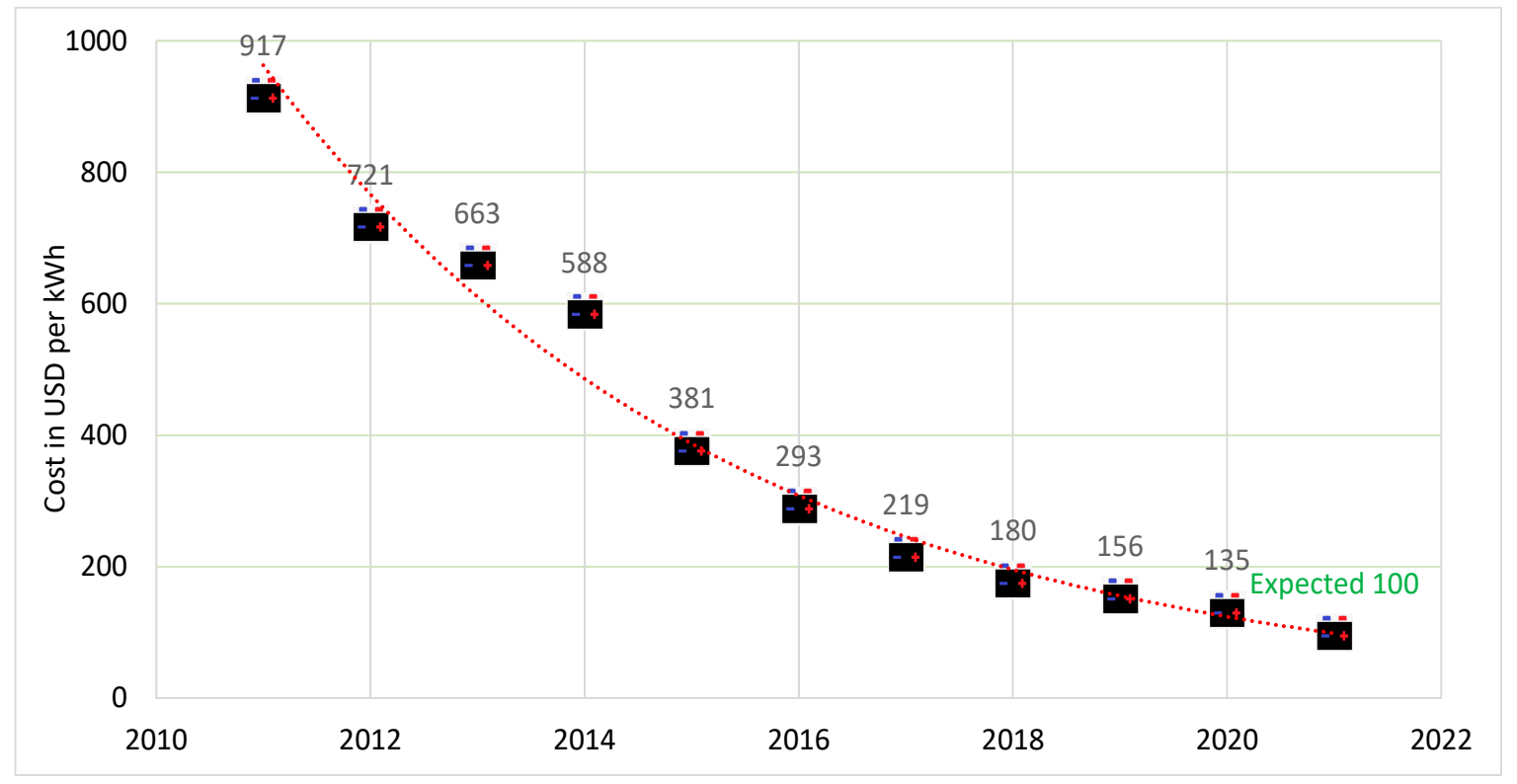

Figure 9. Li-ion battery price in the last decade.

Due to cost-effectiveness, Li-ion batteries are widely used in the energy storage systems of electric and hybrid ferries. Although the Li-ion batteries are cost effective and provide high energy, their life degrades with charging and discharging cycles [28]. Usually, the lifetime of the batteries is calculated in terms of number of charging and discharging cycles rather than calendar time. Typically, the battery life is considered to end when battery performance is reduced by $70-80 \%$ of the early capacity [76]; exact values can be determined from the manufacturer's datasheet. The expected life of a Li-ion battery is 7-10 years, which depends upon charging, discharging cycles, cooling, and physical degradation [47]. 
Compared to lead acid batteries that have low cost but heavy weight, Li-ion batteries are a bit costly but are light enough to be used in electric ferries [28]. In addition, Li-ion batteries can be charged at a fast rate and have good safety specifications [48].

Performance and life of the batteries depends upon operating temperature; therefore, proper cooling is required for battery life as well as for safety. Popular methods include (1) air cooling, (2) liquid cooling (direct and indirect), and (3) fin cooling. Each has trade-offs that include cost, complexity, and power requirements. From an implementation point of view, air cooling is the most inexpensive and simplest technique and depletes the most parasitic power. Liquid cooling is more effective but is also more complex and costly; however, maximum temperature difference can be achieved using indirect liquid cooling. Finally, fins are used for heat removal with uniformity, but extra weight is added in the system compared with the above two methods [49]. The heat dissipated by the battery requires suitable ventilation, otherwise the battery system gets overheated, which not only provides poor performance but also becomes a safety concern.

\section{Discussion}

Based on the data analysis in Section 4, this section first discusses the current state of affairs in Section 5.1, then the associated challenges and emerging trends are highlighted in Section 5.2.

\subsection{Current State of Affairs}

Based on the collected data of various pure electric/hybrid ferries operating in different regions of the world and the case studies, we found that Norway, Denmark, and Scotland are the leading countries for green energy transformation and have designed at least one ferry per year over the last five years. The company, Scandlines (Denmark), has designed four vessels [33,49-51], CalMac Ferries Ltd., (Scotland) has designed three [46-48], while The Fjords (Norway) has designed two ferries [44,45].

The market share of pure electric ferries is $31 \%$ compared to hybrid, i.e., $69 \%$. Pure electric ferries can only travel for short distances due to battery charging requirements, while hybrid vessels use battery technology at lower speeds and in urban areas, especially during docking. Because batteries are heavy and have a large volume, the length of pure electric vessels is small (in the range of 21-39 m), with an average length of $22.5 \mathrm{~m}$ compared to the hybrid vessels, which are long (from 40-160 m), with an average length of $84.5 \mathrm{~m}$. The speed of electric ferries is 7.5-30 knots, with an average speed of 9 knots, while the speed of hybrid vessels is from 7-21 knots with an average speed of 14.75 knots.

The battery capacity of pure electric vessels is $50-500 \mathrm{kWh}$, with an average of $140 \mathrm{kWh}$, while hybrid vessels have 500-5000 kWh, with an average of $1000 \mathrm{kWh}$. From the analysis in Section 4, it is clear that the maximum range in terms of the battery capacity of pure electric vessels is equal to the minimum range in terms of the battery capacity of hybrid vessels, while the average value is also seven times larger; however, both types of vessels use Li-ion battery types, mainly because of economic constraints. The passenger capacity of pure electric ferries is 75-600, with an average of 100 persons, while the capacity of hybrid ferries is 16-2000 persons, with an average of 360 persons. In addition, they can carry several cars in the range of 23-364. The main use of electric and hybrid vessels is in transportation and tourism, i.e., $65 \%$ and $23 \%$, respectively, while the remaining $12 \%$ of hybrid ships are used in multi-purpose and offshore oil and gas sectors.

\subsection{Challenges and Emerging Trends}

Electrification of vessels is a good step towards a pollution and noise free environment. However, there are several challenges associated with the technology, and these can be classified as technical, operational, and legislations.

\subsubsection{Technical}

During a voyage, typically, a ship consumes electrical energy for propulsion and for other purposes in the order of kWh that vary depending upon weather conditions such as wind and currents. 
During charging from the shore, the requirements of ESS (batteries) is in the order of MWh, while the coastline grids (which are designed to provide power for routine tasks) are not strong enough to deliver higher power requirements in a short span; hence, either grid reinforcement or the setting up of a specialized grid station that can be utilized for charging purposes is required.

The grid station design depends upon several factors, e.g., the type and energy requirements of the vessel and duration of stay at the port, as well as the distance between two ports. A typical grid station may cost millions of dollars [32]; however, the actual cost can be estimated after a thorough study based on several factors to cater for the power requirements. Because a large investment is required, a payback period that is based on the utilization of the resources should also be considered. In the case of low traffic, the grid station might be underutilized to obtain financial benefits from the capital spending.

Renewable energies (such as PV energy and wind energy) could also be used for charging, but they are only available in real time. It is quite possible that the energy from renewable resources would be being generated but not consumed completely. Therefore, high capacity battery banks could be used to store renewable energy in different intervals of time at a constant low power. Although the stored power (in battery banks at the port area) can be supplied to the ships' ESS for rapid charging, investment is required to set up renewable energy resources and ESS at the port area.

Safety is another issue to protect the electric ship's power system and the grid or ESS. Because the ship batteries are charged using high power, there is a possibility of arcs at the time of connection and disconnection that might be dangerous and may damage the equipment. Suitable insulation is required between these charging systems and the ESS. Appropriate firefighting systems would also be needed to handle emergency situations.

\subsubsection{Operational}

The technology transformation from fossil fuel to green energy (to improve air quality and reduce noise) is achieved by using Li-ion batteries in electric vessels. Although the materials to design the Li-ion battery are available, scientists have concerns about the availability of materials to design Li-ion batteries; however, this scarcity can be covered by the recycling/waste management of these batteries at the end of life, but this is still a challenge [77,78]. During disassembling and crushing, the physical materials and chemicals may cause bad effects on human health and, therefore, standard recycling methods should be followed for this purpose in order to get maximum economic value with minimum environmental impacts. The overall recycling efficiency of Li-ion batteries can be improved by providing some incentives to the end users to return the batteries at the end of life [77].

Battery technology has improved in the last few years, but the energy density is still too low. Increasing the number of batteries in a vessel is not a practical solution due to size and weight limitations. For this reason, electric vessels require frequent charging of batteries from the ports. Conventionally, electric cables are used to charge electric vessels; alternate methods, e.g., liquid (water) cooled, air-cooled cables, and inductive charging systems for reliability and safety are in use. An efficient transmission cable is required to deliver high voltages without overheating and causing radiation of electrical energy for long periods of time in varying weathers [79].

\subsubsection{Legislation}

There has been a significant growth in electric propulsion in the maritime sector in the last few years, but present regulations from the IMO are preventing rapid development in this area [3]. For example, tax exemption is available for hydro-carbon fuels, while green energy is not in this category [3]. Because green transformation through electrification of vessels is a relatively new technology, suitable education and the training of crew members is also required for better performance and safety. Because the cost (economic) issues are critical and must be addressed to drive ship owners (operators) to go for green transformation, there are certain areas where legislation from concerned authorities is required. Typical examples of these areas are environmental impact, investment payback 
time, modification of existing/design of electric ferries, use of renewable energy, grid station setup, charging mechanisms and energy storage systems in port areas, recycling of batteries, and so on.

\section{Conclusions}

This article presents a knowledge development and implementation guide for the electrification of ferries. First, the current state of affairs has been examined, and implementation guidance to the maritime sector regarding green energy has been provided. A thorough literature review has been carried out, focusing on various attributes of pure electric and hybrid ships, including the vessel types, battery technology, passenger capacity, length, speed, and purpose. The extracted data has been presented in a tabular form. Furthermore, data synthesis has been illustrated using graphical analysis. From the results, it is clear that Norway and Denmark are the leading countries in ship electrification; however, there are several worldwide companies working on electrification. Currently, almost two-thirds of the electrified ships operate in hybrid mode, while the remaining are pure electric. In addition, pure electric ships are not being used for larger distances due to frequent charging requirements, while the hybrid ships are still used for longer distances. Due to the smaller size of pure electric ferries, their passenger capacity is less compared to hybrid ships. Moreover, the major use of electric vessels is in transportation and tourism. Although significant inroads have already been made towards green transformation, a lot still needs to be done. This article also highlights some challenges: technical (setup of a grid station and renewable energy resources in port areas), operational (such as battery energy density and disassembling), and legislation (regulations on tax exemption or rebates) for electrification of vessels in the maritime sector to protect the environment, especially the port areas. The knowledge developed in this article can serve as an implementation guide for policymakers, academia, and other stakeholders for green energy implementation in the maritime sector by reducing emissions and noise while improving performance and comfort.

Author Contributions: Conceptualization, S.A. and G.Z.d.R.; methodology, S.A. and M.Y.I.Z.; software, M.Y.I.Z.; validation, S.A., M.Y.I.Z., G.Z.d.R., and P.E.; formal analysis, M.Y.I.Z. and M.R.; investigation, S.A., M.Y.I.Z., and M.R.; resources, G.Z.d.R. and P.E.; data curation, S.A. and M.Y.I.Z.; writing-original draft preparation, S.A., G.Z.d.R., and P.E.; writing-review and editing, S.A., M.Y.I.Z., and M.R.; visualization, M.Y.I.Z.; supervision, G.Z.d.R. and P.E.; project administration, G.Z.d.R. and P.E.; funding acquisition, G.Z.d.R. and P.E. All authors have read and agreed to the published version of the manuscript.

Funding: This research is funded by Aarhus University, Herning, Denmark.

Acknowledgments: The authors express their gratitude to the Department of Business Development and Technology, Aarhus University, Herning, Denmark, and the Department of Computer Engineering, Umm Al Qura University, Makkah, Saudi Arabia.

Conflicts of Interest: The authors declare no conflict of interest.

\section{References}

1. Schnurr, R.E.; Walker, T.R. Marine Transportation and Energy Use. In Reference Module in Earth Systems and Environmental Sciences; Elsevier: Amsterdam, The Netherlands, 2019. [CrossRef]

2. European Commission, SEC (2005) 1133. Available online: https://ec.europa.eu/transparency/regdoc/rep/2/2 005/EN/2-2005-1133-EN-1-0.pdf (accessed on 10 October 2020).

3. Gagatsi, E.; Estrup, T.; Halatsis, A. Exploring the potentials of electrical waterborne transport in Europe: The E-ferry concept. Transp. Res. Procedia 2016, 14, 1571-1580. [CrossRef]

4. Sciberras, E.A.; Zahawi, B.; Atkinson, D.J. Reducing shipboard emissions-Assessment of the role of electrical technologies. Transp. Res. Part D Transp. Environ. 2017, 51, 227-239. [CrossRef]

5. European Seaports Organisation: ESPO Annual Report for 2006-2007, May 2007. Available online: https://www.espo.be/media/espopublications/annualreport2007.pdf (accessed on 10 October 2020).

6. Klebanoff, L.; Pratt, J.; Leffers, C.; Sonerholm, K.; Escher, T.; Burgard, J.; Ghosh, S. Comparison of the greenhouse gas and criteria pollutant emissions from the SF-BREEZE high-speed fuel-cell ferry with a diesel ferry. Transp. Res. Part D Transp. Environ. 2017, 54, 250-268. [CrossRef] 
7. Merien-Paul, R.H.; Enshaei, H.; Jayasinghe, S.G. In-situ data vs. bottom-up approaches in estimations of marine fuel consumptions and emissions. Transp. Res. Part D Transp. Environ. 2018, 62, 619-632. [CrossRef]

8. McArthur, D.P.; Osland, L. Ships in a city harbour: An economic valuation of atmospheric emissions. Transp. Res. Part D Transp. Environ. 2013, 21, 47-52. [CrossRef]

9. Winnes, H.; Styhre, L.; Fridell, E. Reducing GHG emissions from ships in port areas. Res. Transp. Bus. Manag. 2015, 17, 73-82. [CrossRef]

10. Valladolid, P.G.; Tunestål, P.; Monsalve-Serrano, J.; García, A.; Hyvönen, J. Impact of diesel pilot distribution on the ignition process of a dual fuel medium speed marine engine. Energy Convers. Manag. 2017, 149, 192-205. [CrossRef]

11. Livanos, G.A.; Theotokatos, G.; Pagonis, D.-N. Techno-economic investigation of alternative propulsion plants for Ferries and RoRo ships. Energy Convers. Manag. 2014, 79, 640-651. [CrossRef]

12. Nielsen, R.F.; Haglind, F.; Larsen, U. Design and modeling of an advanced marine machinery system including waste heat recovery and removal of sulphur oxides. Energy Convers. Manag. 2014, 85, 687-693. [CrossRef]

13. Papanikolaou, A.; Eliopoulou, E. The European Passenger Car Ferry Fleet-Review of design features and stability characteristics of pre-and post SOLAS 90 Ro-Ro Passenger ships. In Proceedings of the Euroconference on Passenger Ship Design, Construction, Safety and Operation, Anissaras-Crete, Crete, Greece, 15-17 October 2001.

14. Hansen, J.F.; Wendt, F. History and state of the art in commercial electric ship propulsion, integrated power systems, and future trends. Proc. IEEE 2015, 103, 2229-2242. [CrossRef]

15. Dedes, E.K.; Hudson, D.A.; Turnock, S.R. Assessing the potential of hybrid energy technology to reduce exhaust emissions from global shipping. Energy Policy 2012, 40, 204-218. [CrossRef]

16. Ling-Chin, J.; Roskilly, A. Investigating a conventional and retrofit power plant on-board a Roll-on/Roll-off cargo ship from a sustainability perspective-A life cycle assessment case study. Energy Convers. Manag. 2016, 117, 305-318. [CrossRef]

17. Kim, H.; Koo, K.Y.; Joung, T.-H. A study on the necessity of integrated evaluation of alternative marine fuels. J. Int. Marit. Saf. Environ. Aff. Shipp. 2020, 4, 26-31. [CrossRef]

18. Nguyen, H.P.; Hoang, A.T.; Nizetic, S.; Nguyen, X.P.; Le, A.T.; Luong, C.N.; Chu, V.D.; Pham, V.V. The electric propulsion system as a green solution for management strategy of $\mathrm{CO}_{2}$ emission in ocean shipping: A comprehensive review. Int. Trans. Electr. Energy Syst. 2020, e12580. [CrossRef]

19. Kumar, D.; Zare, F. A comprehensive review of maritime microgrids: System architectures, energy efficiency, power quality, and regulations. IEEE Access 2019, 7, 67249-67277. [CrossRef]

20. Nuchturee, C.; Li, T.; Xia, H. Energy efficiency of integrated electric propulsion for ships-A review. Renew. Sustain. Energy Rev. 2020, 134, 110145. [CrossRef]

21. Groppi, D.; Pfeifer, A.; Garcia, D.A.; Krajačić, G.; Duić, N. A review on energy storage and demand side management solutions in smart energy islands. Renew. Sustain. Energy Rev. 2020, 135, 110183. [CrossRef]

22. Ma, S.; Lin, M.; Lin, T.-E.; Lan, T.; Liao, X.; Maréchal, F.; Yang, Y.; Dong, C.; Wang, L. Fuel cell-battery hybrid systems for mobility and off-grid applications: A review. Renew. Sustain. Energy Rev. 2020, 135, 110119. [CrossRef]

23. Mutarraf, M.U.; Terriche, Y.; Niazi, K.A.K.; Vasquez, J.C.; Guerrero, J.M. Energy storage systems for shipboard microgrids-A review. Energies 2018, 11, 3492. [CrossRef]

24. Fang, S.; Wang, Y.; Gou, B.; Xu, Y. Toward Future Green Maritime Transportation: An Overview of Seaport Microgrids and All-Electric Ships. IEEE Trans. Veh. Technol. 2019, 69, 207-219. [CrossRef]

25. Jeong, B.; Jeon, H.; Kim, S.; Kim, J.; Zhou, P. Evaluation of the lifecycle environmental benefits of full battery powered ships: Comparative analysis of marine diesel and electricity. J. Mar. Sci. Eng. 2020, 8, 580. [CrossRef]

26. Koumentakos, A.G. Developments in Electric and Green Marine Ships. Appl. Syst. Innov. 2019, $2,34$. [CrossRef]

27. Pfeifer, A.; Prebeg, P.; Duić, N. Challenges and opportunities of zero emission shipping in smart islands: A study of zero emission ferry lines. eTransportation 2020, 3, 100048. [CrossRef]

28. Malla, U. Design and sizing of battery system for electric yacht and ferry. Int. J. Interact. Des. Manuf. (IJIDeM) 2020, 14, 137-142. [CrossRef] 
29. Solar Irradiance. Available online: http://www.solarelectricityhandbook.com/solar-irradiance.html (accessed on 10 October 2020).

30. Enevoldsen, P. Onshore wind energy in Northern European forests: Reviewing the risks. Renew. Sustain. Energy Rev. 2016, 60, 1251-1262. [CrossRef]

31. Toffoli, A.; Bitner-Gregersen, E.M. Types of ocean surface waves, wave classification. Encycl. Marit. Offshore Eng. 2017, 1-8. [CrossRef]

32. Bianucci, M.; Merlino, S.; Ferrando, M.; Baruzzo, L. The optimal hybrid/electric ferry for the liguria Natural Parks. In Proceedings of the OCEANS 2015-Genova, Genova, Italy, 18-21 May 2015; pp. 1-10.

33. MF Tycho Brahe-Battery-Electric Car-Ferry. Available online: https://deif-cdn.azureedge.net/v-dj18h6oak hn2/-/media/files/publications/tycho-brahe/tycho-brahe-uk-lowresnewversion082018.pdf?la=en\&hash=C 5B875A237038D5868BABB833AE839773301A158 (accessed on 10 October 2020).

34. Elektra-Hybrid-Electric Ferry. Available online: https://www.ship-technology.com/features/elektra-finland s-first-hybrid-electric-ferry/ (accessed on 10 October 2020).

35. MAN Energy Solutions. Available online: https://greece.man-es.com/docs/librariesprovider11/uptime-anyt ime---12330-6th-june/6_hybrid-solutions-batteries-pto-gensets-mzjr.pdf?sfvrsn=f020c0a2_2 (accessed on 30 November 2020).

36. Scapens, R.W. Doing case study research. In The Real Life Guide to Accounting Research; Elsevier: Amsterdam, The Netherlands, 2004; pp. 257-279. [CrossRef]

37. Rashid, M.; Anwar, M.W.; Khan, A.M. Toward the tools selection in model based system engineering for embedded systems-A systematic literature review. J. Syst. Softw. 2015, 106, 150-163. [CrossRef]

38. Amjad, A.; Azam, F.; Anwar, M.W.; Butt, W.H.; Rashid, M. Event-driven process chain for modeling and verification of business requirements-a systematic literature review. IEEE Access 2018, 6, 9027-9048. [CrossRef]

39. Rashid, M.; Imran, M.; Jafri, A.R.; Al-Somani, T.F. Flexible architectures for cryptographic algorithmsA systematic literature review. J. Circuits Syst. Comput. 2019, 28, 1930003. [CrossRef]

40. FCS Alsterwasser-Zemships. Available online: https:/ec.europa.eu/environment/life/project/Projects/index .cfm?fuseaction=home.showFile\&rep=file\&fil=Zemships_Brochure_EN.pdf (accessed on 10 October 2020).

41. Nemo-First Fuel Cell Boat. Available online: https://www.reuters.com/article/us-dutch-fuelcell-idUSTRE5 B83HD20091209 (accessed on 10 October 2020).

42. Viking Lady-Offshore Supply Vessel. Available online: https://www.ship-technology.com/projects/vikinglady/ (accessed on 10 October 2020).

43. Ellen-The World's Largest E-Ferry. Available online: https://www.euronews.com/2019/11/25/me et-ellen-the-world-s-largest-e-ferry-connecting-two-danish-islands-without-emitting-any (accessed on 10 October 2020).

44. The Future of the Fjords-All Electric Sight Seeing Vessel. Available online: https://www.ship-technology.co $\mathrm{m} /$ projects/future-of-the-fjords-sightseeing-vessel (accessed on 10 October 2020).

45. Vision of The Fjords-The Hybrid Ferry. Available online: https://www.vatnahalsen.no/en/vision-fjords (accessed on 10 October 2020).

46. MV Hallaig—Caledonian Maritime Assets Ltd. Available online: https://www.cmassets.co.uk/project/mv-ha llaig (accessed on 10 October 2020).

47. MV Lochinvar-Caledonian Maritime Assets Ltd. Available online: https://www.cmassets.co.uk/project/mvlochinvar/ (accessed on 10 October 2020).

48. MV Catriona-Caledonian Maritime Assets Ltd. Available online: https://www.cmassets.co.uk/project/mvcatriona/ (accessed on 10 October 2020).

49. MV Prinsesse Benedikte-Hybrid Ferry. Available online: https://www.scandlines.com/about-scandlines/ab out-scandlines-frontpage/ferries-and-ports/prinsesse-benedikte (accessed on 10 October 2020).

50. MV Prins Richard-Hybrid Ferry. Available online: https://www.scandlines.com/about-scandlines/about-sc andlines-frontpage/ferries-and-ports/prins-richard (accessed on 10 October 2020).

51. M/F Deutschland-Scandlines Deutschland GmbH. Available online: http://www.ferry-site.dk/ferry.php?id $=9151541 \&$ lang $=$ en (accessed on 10 October 2020).

52. M/S Sjovagen-Electric Powered Ferry. Available online: https://www.greenport.com/news101/europe/new -electric-ferry-unveiled-in-sweden (accessed on 10 October 2020). 
53. Movitz-The World’s First Supercharged Ferry. Available online: https://echandia.se/echandia/projects/mo vitz/ (accessed on 10 October 2020).

54. Ampere-A Battery-Electric Ferry. Available online: https://archive.nordregio.se/en/Publications/Publication s-2016/GREEN-GROWTH-IN-NORDIC-REGIONS-50-ways-to-make-/Clean-tech-and-renewable-energy --/Amper/index.html (accessed on 10 October 2020).

55. MV Island Clipper-Offshore Service Vessel. Available online: https://www.islandoffshore.com/vessel/mv-i sland-clipper (accessed on 10 October 2020).

56. OV Bokfjord-Multipurpose Vessel. Available online: https://hvsa.dk/portfolio_page/ov-boekfjord/ (accessed on 10 October 2020).

57. Viking Princess-Hybrid Energy System on Board the Offshore Supply Vessel. Available online: https: //newpowerprogress.com/offshore-supply-vessel-goes-hybrid/ (accessed on 10 October 2020).

58. Zhongtiandianyun 001—Electric Cargo Ship. Available online: https://plugboats.com/china-launches-electri c-cargo-ship-to-carry-coal/ (accessed on 10 October 2020).

59. Enhydra-Hybrid Ferry. Available online: https://www.greenbiz.com/article/future-ferries-electric-too (accessed on 10 October 2020).

60. MV Waterman-Passenger Catamaran Ferry. Available online: https://www.pacmar.com/story/2019/04/01/fe atures/propulsion/693.html (accessed on 10 October 2020).

61. BB Green-Electric Commuter Ferry. Available online: https://www.volvopenta.com/marinecommercial/en -en/news/2017/june/bb-green-electric-commuter-ferry-awarded-electric-and-hybrid-pro.html (accessed on 10 October 2020).

62. Aditya-Solar-Powered Ferry. Available online: https://en.wikipedia.org/w/index.php?title=Aditya_(boat)\& oldid=954179830 (accessed on 10 October 2020).

63. MS Color-Hybrid Ferry. Available online: https://www.ship-technology.com/projects/color-hybrid-ferry/ (accessed on 10 October 2020).

64. Spagnolo, G.S.; Papalilo, D.; Martocchia, A. Eco friendly electric propulsion boat. In Proceedings of the 2011 10th International Conference on Environment and Electrical Engineering, Rome, Italy, 8-11 May 2011; pp. 1-4.

65. Al-Falahi, M.D.; Nimma, K.S.; Jayasinghe, S.D.; Enshaei, H.; Guerrero, J.M. Power management optimization of hybrid power systems in electric ferries. Energy Convers. Manag. 2018, 172, 50-66. [CrossRef]

66. Meek-Hansen, B. Fuel cell technology for ferries. In Proceedings of the IMTA Conference, Gold Coast: Marintek, Ottawa, ON, Canada, 22-24 October 2002; pp. 1-12.

67. Diab, F.; Lan, H.; Ali, S. Novel comparison study between the hybrid renewable energy systems on land and on ship. Renew. Sustain. Energy Rev. 2016, 63, 452-463. [CrossRef]

68. Bassam, A.M.; Phillips, A.B.; Turnock, S.R.; Wilson, P.A. An improved energy management strategy for a hybrid fuel cell/battery passenger vessel. Int. J. Hydrog. Energy 2016, 41, 22453-22464. [CrossRef]

69. Bassam, A.M.; Phillips, A.B.; Turnock, S.R.; Wilson, P.A. Development of a multi-scheme energy management strategy for a hybrid fuel cell driven passenger ship. Int. J. Hydrog. Energy 2017, 42, 623-635. [CrossRef]

70. Feng, Y.; Chen, L.; Dong, Z. Modeling, Simulation and Assessment of a Hybrid Electric Ferry: Case Study for Mid-Size Ferry. In Proceedings of the International Design Engineering Technical Conferences and Computers and Information in Engineering Conference, Anaheim, CA, USA, 18-21 August 2019; p. V009T012A028.

71. Bassam, A.; Phillips, A.; Turnock, S.; Wilson, P.A. Design, modelling and simulation of a hybrid fuel cell propulsion system for a domestic ferry. In Proceedings of the 13th International Symposium on PRActical Design of Ships and Other Floating Structures (PRADS' 2016), Copenhagen, Denmark, 4-8 September 2016; Technical University of Denmark: Lyngby, Denmark, 2016; pp. 545-553.

72. Han, J.; Charpentier, J.-F.; Tang, T. An energy management system of a fuel cell/battery hybrid boat. Energies 2014, 7, 2799-2820. [CrossRef]

73. Leading Companies in Lithium Ion Battery Market. Available online: https://www.aheadintel.com/leading-c ompanies-lithium-ion-battery-market/ (accessed on 30 November 2020).

74. Lithium-Ion Battery Costs and Market. Available online: http://enerjiye.com/wp-content/uploads/2018/12/ba ttery-market.pdf (accessed on 30 November 2020).

75. Dai, Q.; Kelly, J.C.; Gaines, L.; Wang, M. Life cycle analysis of lithium-ion batteries for automotive applications. Batteries 2019, 5, 48. [CrossRef] 
76. Martinez-Laserna, E.; Sarasketa-Zabala, E.; Stroe, D.-I.; Swierczynski, M.; Warnecke, A.; Timmermans, J.-M.; Goutam, S.; Rodriguez, P. Evaluation of lithium-ion battery second life performance and degradation. In Proceedings of the 2016 IEEE Energy Conversion Congress and Exposition (ECCE), Milwaukee, WI, USA, 18-22 September 2016; pp. 1-7.

77. Gaines, L.; Richa, K.; Spangenberger, J. Key issues for Li-ion battery recycling. MRS Energy Sustain. $2018,5$. [CrossRef]

78. Oliveira, L.; Messagie, M.; Rangaraju, S.; Sanfelix, J.; Rivas, M.H.; Van Mierlo, J. Key issues of lithium-ion batteries-from resource depletion to environmental performance indicators. J. Clean. Prod. 2015, 108, 354-362. [CrossRef]

79. Chen, D.; Jiang, J.; Kim, G.-H.; Yang, C.; Pesaran, A. Comparison of different cooling methods for lithium ion battery cells. Appl. Therm. Eng. 2016, 94, 846-854. [CrossRef]

Publisher's Note: MDPI stays neutral with regard to jurisdictional claims in published maps and institutional affiliations.

(C) 2020 by the authors. Licensee MDPI, Basel, Switzerland. This article is an open access article distributed under the terms and conditions of the Creative Commons Attribution (CC BY) license (http://creativecommons.org/licenses/by/4.0/). 